\title{
RELATIVE SEA-LEVEL CHANGES NEAR HELSINKI, SOUTHERN FINLAND, DURING EARLY LITORINA TIMES
}

\author{
HANNU HYVÄRINEN
}

\begin{abstract}
HYVÄRINEN, H. 1980: Relative sea-level changes near Helsinki, southern Finland, during early Litorina times. Bull. Geol. Soc. Finland 52-2, 207-219.

Recent stratigraphical and radiocarbon data, complemented by archaeological data, were used to construct a shore displacement curve for the Helsinki area. Trends during Mastogloia and early Litorina times between 8000 and 6000 years ago could be traced in particular. Owing to a near equilibrium between land uplift and eustatic sea-level rise, the relative sea level at Helsinki was stable or slightly transgressive during the first part of this interval until about 7000-6500 years ago. This was followed by an even, slow regression. With a margin of uncertainty of about one metre, the available data do not indicate any short-term fluctuations in the relative sea level and are therefore consistent with an even rise of the ocean level during the interval concerned, that is, from 8000 to 6000 years ago.
\end{abstract}

Hannu Hyvärinen, Department of Geology, Division of Geology and Palaeontology, University of Helsinki, Snellmaninkatu 5, SF-00170 Helsinki 17, Finland.

\section{Introduction}

In the history of the Baltic, the Litorina stage in its broadest sense began when the eustatic rise of the sea level reached the Straits of Denmark, and the Baltic basin was reconnected with the ocean after the lacustrine Ancylus stage. When and how exactly this happened is not quite clear. Stratigraphically, the Ancylus stage was succeeded by a metachronous transition stage of weak salinity, called the Mastogloia Sea, which in southern Sweden started well over 8000 years B.P. (Berglund 1964). The earliest sediments assigned to this stage on the Finnish coast date from about 8000 B.P. (Alhonen 1971, Eronen 1974). The beginning of the Litorina Sea in a strict sense is usually placed at between 7500 and 7000 B.P., a time when a more pronounced increase in salinity can be traced in the Baltic sediments. Even this stratigraphical horizon, called the Clypeus limit after its characteristic diatom (in Iittoral facies) Campylodiscus clypeus, is somewhat metachronous within the Baltic. In southern Finland its age is about 7300 B.P., whereas in the northern parts of the Gulf of Bothnia ages closer to 7000 B.P. have been obtained (Eronen 1974, Alhonen et al. 1978).

The Litorina sea was transgressive in the southern and eastern sector of the Baltic, where the isostatic land uplift was zero or slower than the eustatic sea-level rise. In central and northern parts of the basin a continuous regression of shore level prevailed throughout Litorina times because of the higher rate of land uplift. The present area near Helsinki (Fig. 1) belongs to a zone of 


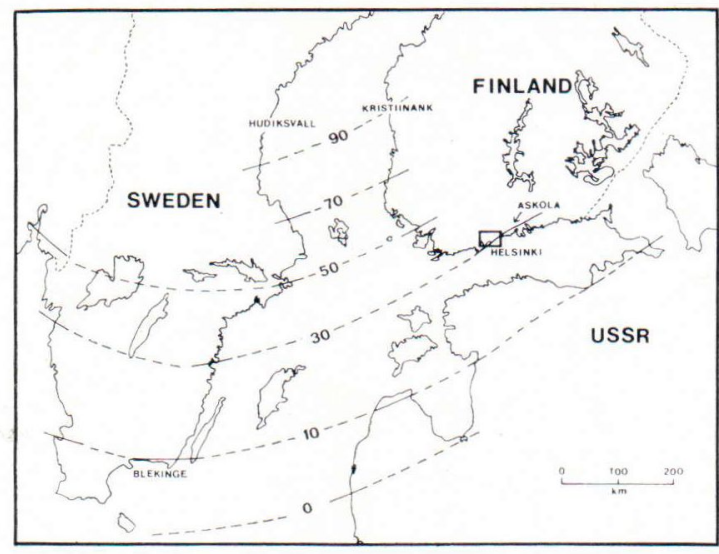

Fig. 1. Location of the area investigated near Helsinki and the isobases of the Litorina Sea about 7000 years ago in metres above the present sea level.

transition between the clearly regressive and transgressive Litorina coasts. Unequivocal stratigraphical indications of transgression are present along the southern Finnish coast east of Helsinki, where the modern uplift is currently less than $3 \mathrm{~mm} / \mathrm{yr}$ and the highest Litorina limit is less than about $30 \mathrm{~m}$ above the present sea level (see, e.g. Eronen 1974, Fig. 8). The Helsinki area has generally been assumed to have experienced a transgression of a few metres, but here the evidence is less conclusive. On the basis of stratigraphical evidence, I recently suggested (Hyvärinen 1979) that the amplitude of the transgression at Helsinki must have been very small and that in early Litorina times there was a period of near equilibrium between land uplift and eustatic movement in this area. This suggestion is borne out by the present results.

One of the main controversies in the history of the Litorina Sea is the number of transgressions. Authors have usually distinguished several successive peaks of transgression within the Litorina episode (e.g. Berglund 1964, 1971). The exact number and dating of these phases varies with the different authors, but, generally speaking, the concept of a multi-transgression Baltic Lito- rina corresponds to the eustatic models that show several short-term fluctuations of the sea level superimposed on the main trend (e.g. Fairbridge 1961). On the other hand, Eronen (1974) has argued that the Baltic data are best interpreted in terms of a single, broad eustatic transgression peaking between 6000 and 4000 years B.P. Obviously, areas such as Helsinki, where the shore level has remained broadly stable for a time interval of some length, are potentially suitable for tracing any secondary fluctuations in the sea level during that interval and for testing the different sea-level models. There are practically no tides in the Baltic.

In recent years several radiocarbon-dated stratigraphical sites relevant to the history of the Litorina Sea have been published from the Helsinki area (Alhonen 1972, Eronen 1974, Alhonen et al. 1978, Hyvärinen 1979). I shall now describe a new site (Odilampi), which was chosen because of its critical position near the highest Litorina limit. By comparing this site with the previous ones and with archaeological sea level indicators, it is possible to reconstruct a relative sea-level curve that is fairly accurate for the early Litorina period.

Fig. 2 shows the location of the sites and the approximate position and tilt of the highest Litorina limit near Helsinki. The Litorina isobases shown here are based on the present material. Note that they deviate from the isobases in Hyvärinen 1979 which were drawn according to Hyyppä (1950).

\section{Odilampi}

Site description and chronology

Odilampi $\left(60^{\circ} 18^{\prime} \mathrm{N}, 24^{\circ} 46^{\prime} \mathrm{E}\right)$ is a small, shallow lake, about 300 by $100 \mathrm{~m}$ in size, at the border of the towns of Espoo and Vantaa about $17 \mathrm{~km} \mathrm{NW}$ of Helsinki. Originally, the lake must have covered a much larger part 


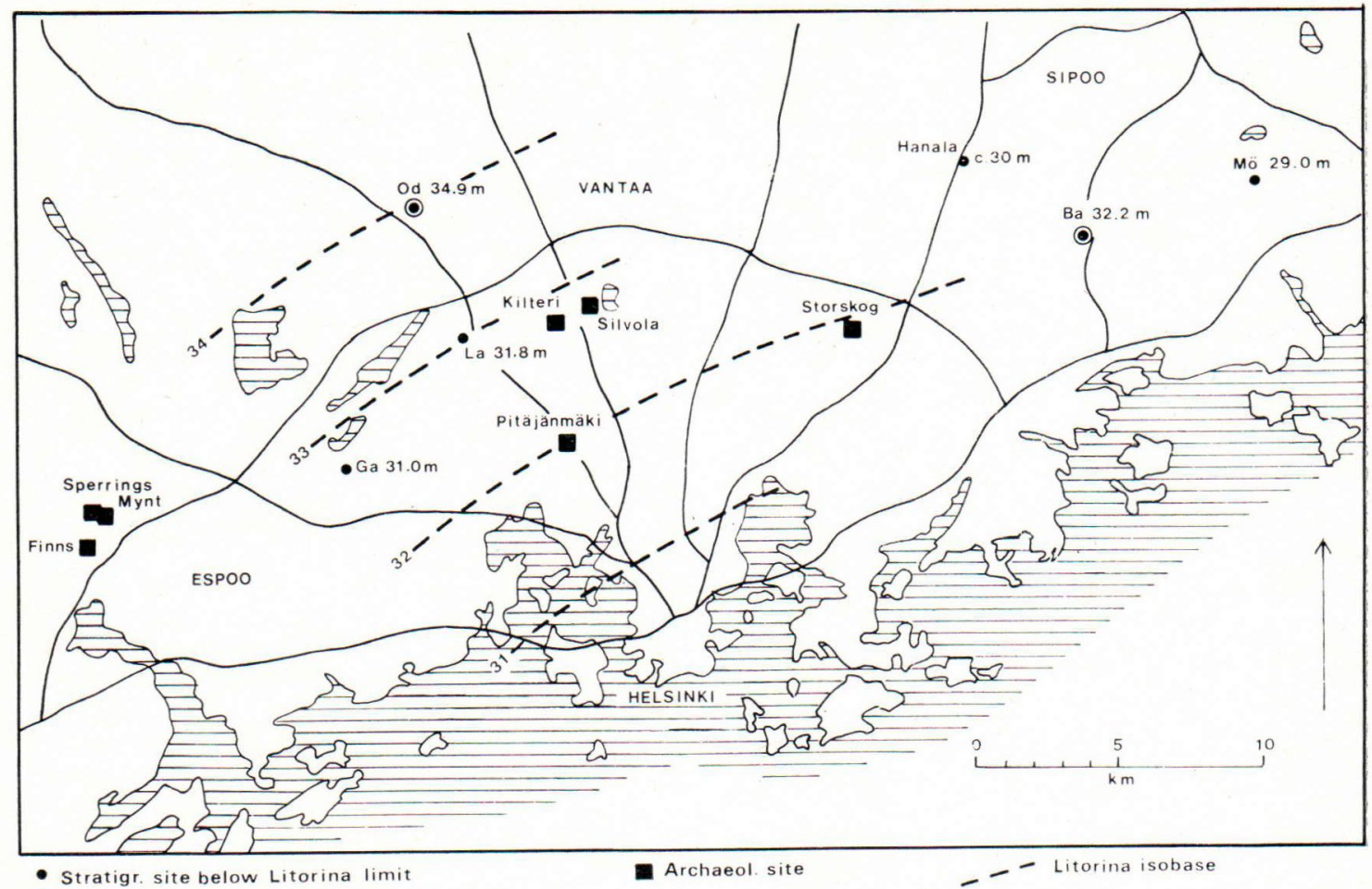

- Stratigr. site below Litorina limit

- Stratigr. site at or above Litorina limit

Fig. 2. Map of the Helsinki area, showing the sites used for constructing the shore displacement curve (Fig. 5), and the isobases for the highest Litorina limit. References to the stratigraphical sites: $\mathrm{Od}=$ Odilampi (present paper), $\mathrm{Ba}=$ Bakunkärrsträsket (Hyvärinen 1979), La = Lammaslampi (Alhonen et al. 1978), Ga $=$ Gallträsket (Alhonen 1972, Eronen 1974). Mö = Möträsket (Eronen 1974) and Hanala (Hyyppä 1937) lack radiocarbon dates and were not used. The figures are metres above the present sea level.

of the surrounding depression which is now paludified along the margins. The threshold is $34.9 \mathrm{~m}$ above the present sea level. The lake was sampled from the ice in March 1979 with a piston corer (tube length $100 \mathrm{~cm}$, diameter $5 \mathrm{~cm}$ ). Successive cores were taken through $8.3 \mathrm{~m}$ of sediment. The stratigraphy from top to bottom is as follows:

0-370 cm, dark-brown gyttja with abundant plant detritus

$370-600 \mathrm{~cm}$, greenish-brown fine gyttja $600-720 \mathrm{~cm}$, pale, greenish clay gyttja grading into gyttja clay

$720-830 \mathrm{~cm}$, grey, homogeneous silty clay with occasional thin, black bands of sulphide
The change in sediment types is gradual and without any distinct visual boundaries. The organic content (ignition loss, Fig. 4) also rises gradually, with some minor fluctuations, from below $3 \%$ in the basal part of the profile to nearly $40 \%$ in the lower part of the brown gyttja.

In its main features the pollen stratigraphy (Fig. 3) is quite regular and can be described in terms of the regional pollen assemblage zones for SW Finland as defined by Donner (1971). The lowermost section of the diagram belongs to the Pine Zone, corresponding approximately to the Boreal chronozone (9000-8000 B.P.), and the upper section to the Birch-alder-hazel-elm Zone, correspond- 


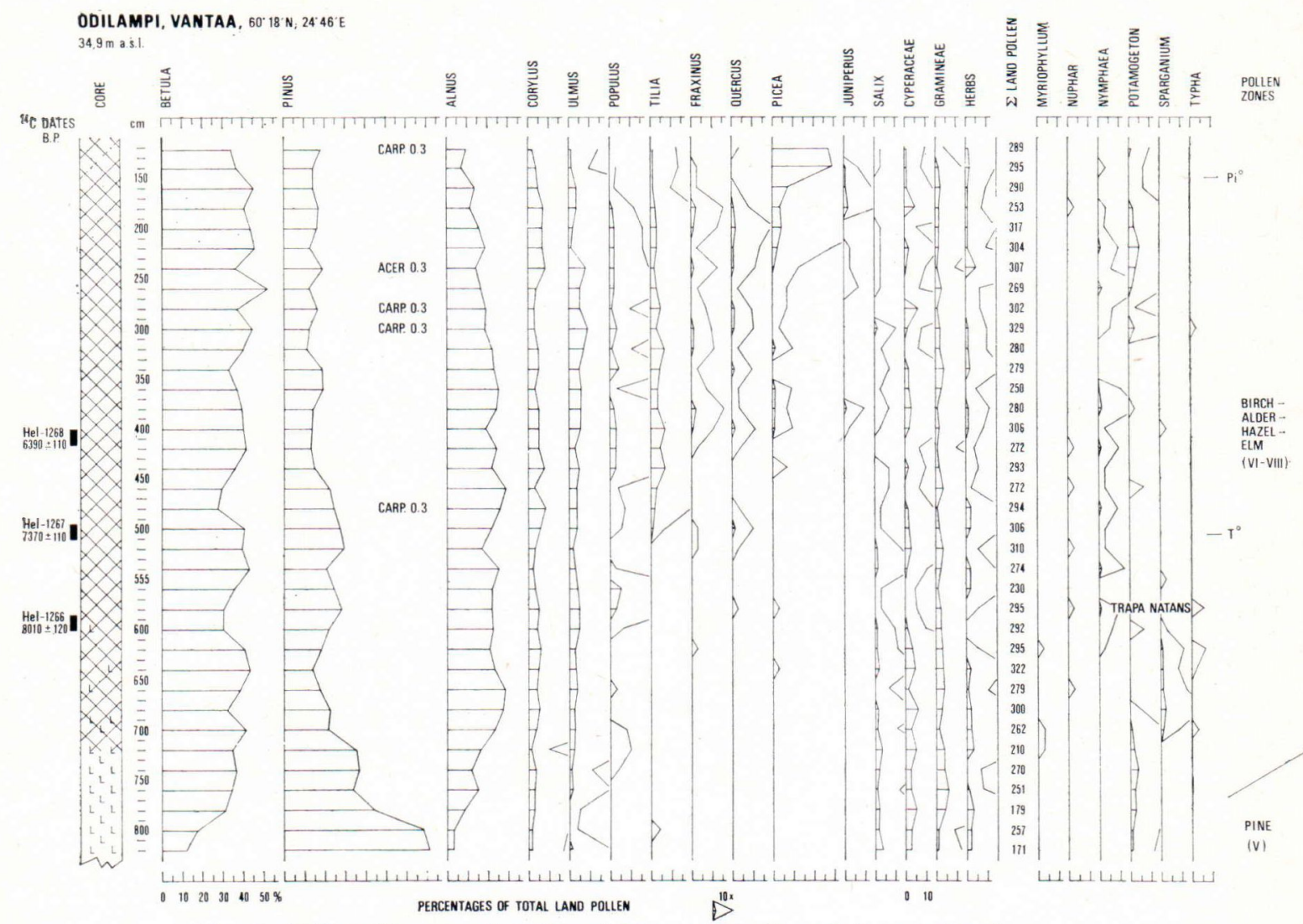

Fig. 3. Pollen diagram of Odilampi. For sediment symbols, see Fig. 4.

ing to the Atlantic and Subboreal chronozones (8000-2500 B.P.). The topmost part of the sediment column above the rise of spruce was not analysed. The upper boundary of the Pine Zone is defined by the rational limit for alder, but in Odilampi this limit is not very distinct, partly because of the relatively rapid sedimentation and partly because the clays may contain some derived alder pollen. Mention has often been made of the difficulties of defining this boundary in fine mineral sediments from the coastal areas (Eronen 1974, Alhonen et al 1978, Hyvärinen 1979). Some locally useful points of reference within the Birch-alder-hazel-elm Zone are the rational limits for lime $\left(\mathrm{T}^{\circ}\right)$ and spruce $\left(\mathrm{Pi}^{\circ}\right)$, for which a number of radiocarbon dates are available from this area; the former has been dated to between 7500 and 7000 B.P. and the latter to about 4000 B.P. (Aartolahti 1966, 1967, Donner 1972, Eronen 1974, Alhonen et al. 1978). Three samples from Odilampi were dated at the Radiocarbon Dating Laboratory, University of Helsinki. The following results, as well as all the other radiocarbon ages in this paper, are expressed in conventional, uncorrected radiocarbon years (T1/2 $5568 \pm 30)$.

\begin{tabular}{lccc}
\hline Sample & $\begin{array}{c}\text { Depth cm } \\
\text { below top } \\
\text { of section }\end{array}$ & Lab. Nr. & Age B.P. \\
\hline 1/Od & $585-600$ & Hel-1266 & $8010 \pm 120$ \\
$2 /$ Od & $495-510$ & Hel-1267 & $7370 \pm 110$ \\
$3 /$ Od & $400-415$ & Hel-1268 & $6390 \pm 110$ \\
\hline
\end{tabular}




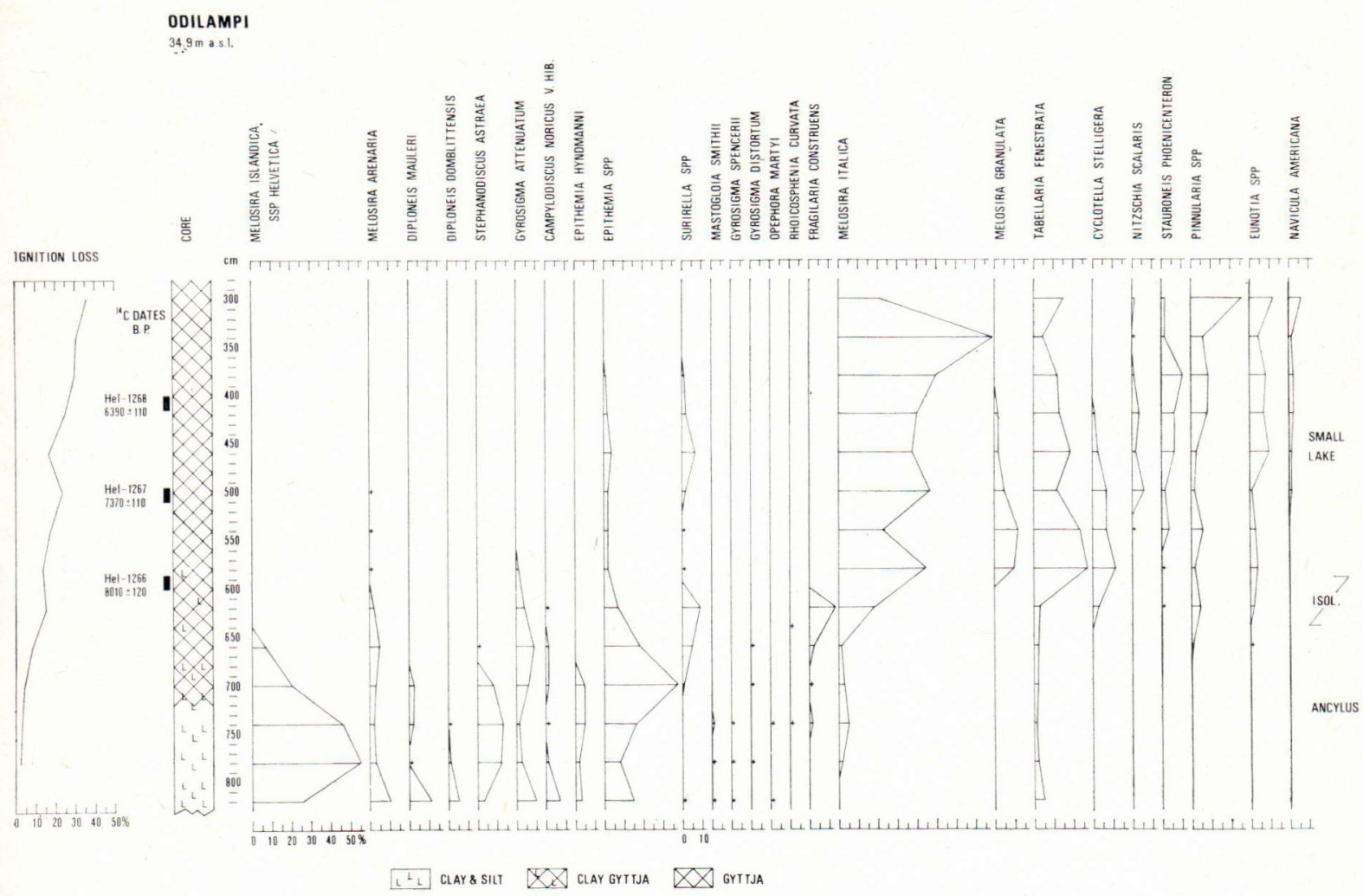

Fig. 4. Diatom diagram of Odilampi. Selected species.

The results are mutually consistent and in good agreement with previous datings for $\mathrm{T}^{\circ}$ and $\mathrm{Pi}^{\circ}$. They are, however, not consistent with the traditional dating to about 8000 B.P. of the upper boundary of the Pine Zone (rise of alder); although the dates do not directly relate to this boundary, a clearly higher age would seem to be indicated for it. A similar discrepancy was found in the nearby profiles of Lammaslampi (Alhonen et al. 1978) and Bakunkärrsträsket (Hyvärinen 1979). This discrepancy disappears if the rise of alder is dated at an age about 500 years higher, as was suggested in a recent study by Donner et al. (1979) based on close radiocarbon dating of two pollen diagrams from near Lahti, about $100 \mathrm{~km}$ north of Helsinki.
Diatom stratigraphy and the history of the basin

The Odilampi sediments were analysed for diatoms from $300 \mathrm{~cm}$ downwards to determine the point at which the basin was cut off from the Baltic (point of isolation) and to identify the preceding Baltic stages. As the rate of sedimentation is quite rapid, a sample interval of $20 \mathrm{~cm}$ was used. Checks made at closer intervals did not reveal any further details. Between 200 and 500 diatom valves were counted for each sample. Fig. 4 shows the main features of the diatom stratigraphy.

The flora of the lower part of the diagram is characterized by species such as Melosira islandica ssp. helvetica, Stephanodiscus astraea, Gyrosigma attenuatum, Diploneis 
mauleri, and Epithemia hyndmannii. All of these belong to the flora typical of the Ancylus Lake sediments. The lowermost clays, which are dominated by pelagic plankton forms (M. islandica, S. astraea), represent a relatively deep facies. A gradual shoaling upwards is indicated by an increase in littoral forms (Epithemia, Surirella), at the same time as the clays grade into clay gyttjas. A distinct change in diatoms takes place above $650 \mathrm{~cm}$ : most of the species present below this horizon disappear and are replaced by a typical small-lake flora, with Melosira italica and Tabellaria fenestrata as the dominant species. This change must reflect the isolation of Odilampi from the Baltic. The appearance of Nuphar, Nymphaea and Trapa in the pollen flora is also consistent with a small-lake environment.

In terms of diatoms and sediments, there is a broad stratigraphical transition from about 650 to $600 \mathrm{~cm}$ that reflects the change to small-lake conditions. Owing to the flat topography of the threshold area and the relatively slow shore-level displacement this change was obviously a gradual one. What is more, the lake was originally larger and deeper than it is at present. The lowermost radiocarbon sample (Hel-1266) relates to a point of marked increase in small-lake diatoms that is somewhat later than the most distinct change in the sediments. The date $8010 \pm 120$ B.P. should therefore give a minimum age for the isolation of Odilampi. In other words, at this date at the latest, the threshold of the basin must have risen above the Baltic water level.

As mentioned before, traces of slight salinity associated with the Mastogloia Sea start to appear in Baltic sediments along the Finnish coast shortly after 8000 B.P. In the present area, for example, a sample from Lammaslampi assigned to this stage was dated at about 7750 B.P. (see below). No clear indications of the Mastogloia stage are present in Odilampi. A few scattered halophilous diatoms appear in the basal part of the profile, but no more than is usual in Ancylus sediments. Thus, the date of about 8000 B.P. for the isolation of Odilampi is in good agreement with the diatom evidence.

The occurrence of the diatom Nitzschia scalaris in several successive samples from $500 \mathrm{~cm}$ upwards needs a comment. According to the radiocarbon dates, these layers date from the Litorina period. $N$. scalaris is a halophilous species and a nearly constant member of the brackish Clypeus flora in Litorina lagoons. However, some of the Clypeus forms have often been found in small amounts from sediments belonging to the lacustrine phase of basins cut off from the Baltic (M.-B. Florin 1946, Eronen 1974, p. 153). Particularly worthy of mention in this context are the observations from modern coastal lakes made by Fontell (1926).

Fontell investigated samples of surface sediment and water plants from 21 small lakes on the Finnish coast situated at a distance from $100 \mathrm{~m}$ to about $2000 \mathrm{~m}$ from the sea. In all of these some salt- and brackish-water diatoms were found mixed with the dominant fresh-water flora. Most of the over 50 saline taxa reported by Fontell only occurred sporadically and were probably derived from older sediments or introduced by birds or spray. Some species, however, including $N$. scalaris, $N$. tryblionella, Campylodiscus clypeus, C. echeneis, Amphora mexicana, and Surirella striatula, were present so regularly that they must have grown in the lakes. Of these, N. scalaris was the most constant. It was found in 18 (out of 21) lakes; in four cases it occurred "generally" in the samples and in one case »in masses».

Obviously, in the absence of other indications, the occurrence of $N$. scalaris in Odilampi must not be taken as evidence of a sea connexion; it merely reflects the proximity of the basin to the Litorina shore. 


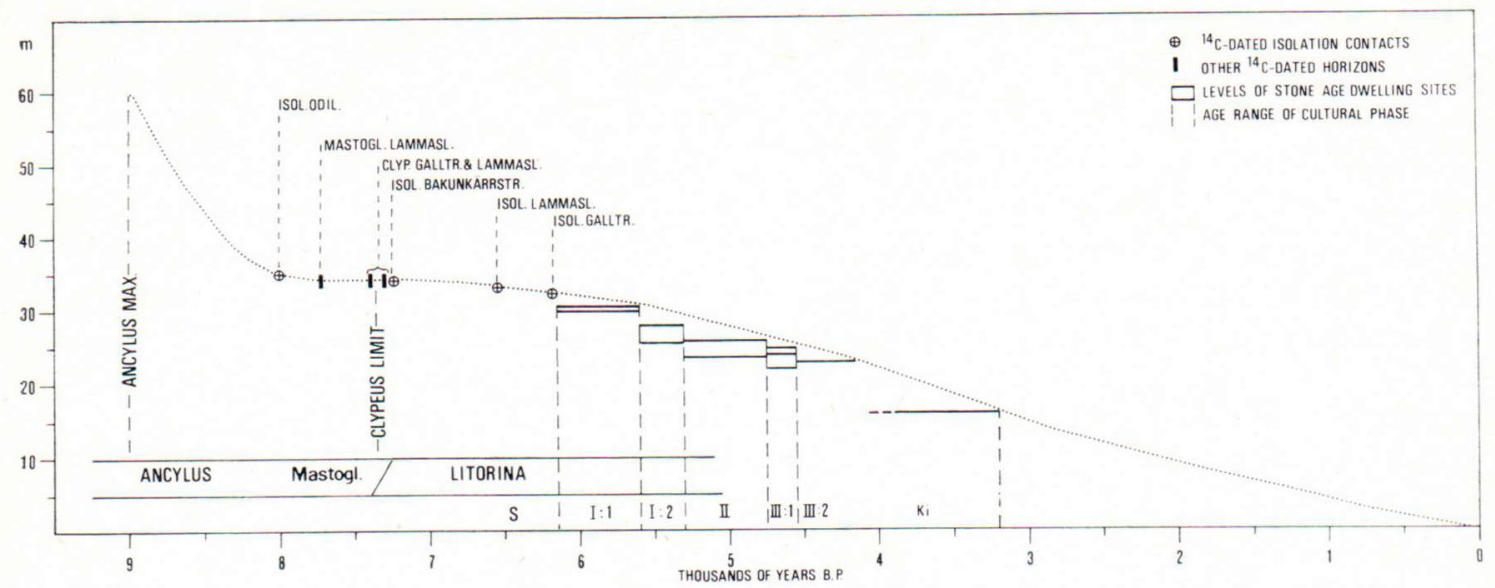

Fig. 5. Shore displacement curve for the $34 \mathrm{~m}$ Litorina isobase near Helsinki.

\section{Shore level changes}

\section{Stratigraphical data}

The conclusions about the Baltic shore level changes are illustrated by the shore displacement curve in Fig. 5. The following sites besides Odilampi were used.

Gallträsket, $31 \mathrm{~m}$ a.s.l. (Alhonen 1972, Eronen 1974). This basin is below the Litorina limit and contains sediments of the Litorina and Ancylus (or Mastogloia) stages underlying the small-lake sediments. The Clypeus limit was dated at $7410 \pm 250$ B.P. (Hel-351) and the isolation contact at $6180 \pm 230$ B.P. (Hel-350). Lammaslampi, $31.8 \mathrm{~m}$ a.s.l. (Alhonen et al. 1978). This basin, which is also below the Litorina limit, is stratigraphically similar to the previous basin. The isolation contact was dated at $6550 \pm 170$ B.P. (Hel999). The Clypeus limit is bracketed by two dates: $7450 \pm 160$ (Hel-997) and $7310 \pm 170$ B.P. (Hel-998). A sample from below the Clypeus limit representing the Mastogloia stage was dated at $7740 \pm 170$ B.P. (Hel996).

Bakunkärrsträsket, $32.2 \mathrm{~m}$ a.s.l. (Hyvärinen 1979). The basin was isolated from a weakly brackish lagoon at $7250 \pm 120$ B.P. (Hel-1131). The lower limit of the brackish horizon, which is underlain by Ancylus sediments, was dated at $8010 \pm 120$ B.P. (Hel-1130). At first, I considered these dates uncertain because they seemed to be somewhat too old in comparison with the upper boundary of the Pine Zone. However, if this boundary is older than has previously been assumed (see above), the inconsistency is largely removed. Taken at their face value, the dates suggest that the basin was isolated from the Mastogloia/ Litorina transition. This agrees well with the weakly brackish character of the diatom flora and is consistent with the altitude of the basin.

None of these basins showed evidence of a renewed connexion with the Baltic after their isolation.

Because the sites are not on the same isobase of land uplift, their vertical positions relative to one another have changed since the time they vere cut off from the Baltic. The shore displacement curve was constructed for the isobase of Odilampi, which is the site farthest in the direction of increasing land uplift. The rest of the sites have been subject to less uplift and their altitudes must be corrected accordingly. The correction used is based on the tilt of $20 \mathrm{~cm} / \mathrm{km}$ of the Baltic shore lines formed between 6500 and 7000 years ago (e.g. Donner 
1970). Strictly speaking, different corrections should have been used for the different stratigraphical points of reference according to their age, which varies from 8000 to 6000 B.P. Since, however, the total corrections are relatively small this factor is not significant. Perpendicular to the isobases, the distance of Lammaslampi from Odilampi is about $5 \mathrm{~km}$, which means that its altitude relative to Odilampi must be raised by one metre to represent the situation in early Litorina times. The corresponding figures for Bakunkärrsträsket are $10 \mathrm{~km}$ and two metres. The correction for Bakunkärrsträsket is somewhat less accurate than for Lammaslampi, because its distance from Odilampi parallel to the isobases is larger, and the course of the isobases is not known exactly; the error cannot be large, however.

Thus, if the altitude of Odilampi in round figures is $35 \mathrm{~m}$ a.s.1., the corrected altitude for Bakunkärrsträsket is $34 \mathrm{~m}$ and for Lammaslampi $33 \mathrm{~m}$. Gallträsket must be placed about $0.5 \mathrm{~m}$ below Lammaslampi. The successive isolations of these basins fix the position of the shore level for nearly 2000 years: between 8000 and 7250 yr B.P. the shore level must have been below Odilampi and above Bakunkärrsträsket (and Lammaslampi), and between 7250 and 6550 yr B.P. it must have been below Bakunkärrsträsket (and Odilampi) and above Lammaslampi. By 6550 yr B.P. it had dropped below Lammaslampi and by 6200 yr B.P. below Gallträsket.

Alhonen et al. (1978) were able to show in the sediments of Lammaslampi a small fluctuation in the ignition loss values, corresponding to a narrow silty horizon between the Clypeus limit and the isolation contact. This they assumed to reflect a Litorina transgression, which according to earlier estimates would have had an amplitude of 2-3 metres near Helsinki. However, the other sites give no indications of a transgres- sion. The silty horizon in Lammaslampi may have formed during a broadly stable sea level, possibly with a slight transgressive trend, or it may have some other explanation. The overall evidence suggests that if any Litorina transgression took place near Helsinki, its amplitude cannot have been more than about one metre.

The part of the shore displacement curve describing the regression before 8000 yr B.P. is tentative. The results by Eronen (1976) for an area east of Helsinki indicate that the peak of the Ancylus transgression occurred about 9000 yr ago, and it can be estimated that the water level at Helsinki must then have stood at around $60 \mathrm{~m}$ a.s.l. Although the exact course of the curve cannot be determined from the present data, there must have been a rapid change in the shore displacement trend between 8000 and 8500 yr B.P.: the steep regression after $9000 \mathrm{yr}$ B.P., the combined effect of the land uplift and the drop in the level of the Ancylus Lake, was followed by a period of a nearly stable relative sea level. The marked retardation in the shore displacement must have coincided with the event when the Baltic became connected with the ocean and the effect of the eustatic component began to be felt.

\section{Archaelogical data}

Reliably dated stratigraphical sites for tracing the shore level history after $6000 \mathrm{yr}$ B.P. are not available. This later development can nevertheless be illustrated by means of archaeological evidence from Stone Age water-side dwelling places. For the Stone Age chronology and the relation of the archaeological sites to the Baltic shore levels, the reader is referred to Siiriäinen (1969, 1972, 1973). The sites from near Helsinki used in this study are listed below (Table 1.), and their location is shown in Fig. 2. The data are from Siiriäinen (1969) and from the 
Table 1. List of archaeological sites.

$\begin{array}{ccc}\text { Espoo, Sperrings } & & \\ \text { Ka I :1 } & 30.5 & \mathrm{~m} \\ \text { Ka I:2 } & 28 & \mathrm{~m} \\ \text { Espoo, Finns } & & \\ \text { Ka II:1 } & 26 & \mathrm{~m} \\ \text { Ka III:1 } & 25 & \mathrm{~m} \\ \text { Ka III:2 } & 23 & \mathrm{~m} \\ \text { Ki } & 16 & \mathrm{~m}\end{array}$

Espoo, Mynt

Ka III:1 $24 \mathrm{~m}$

Helsinki, Pitäjänmäki

Ka II:1 $\quad 23.5 \mathrm{~m}$

Ka II :2 $23.5 \mathrm{~m}$

Ka III:1 $22 \quad \mathrm{~m}$

Helsinki, Storskog

$\mathrm{Ka} \mathrm{I}: 2 \quad 25.5 \mathrm{~m}$

Helsinki, Silvola (Kaarela)

Ka I:1

$30 \mathrm{~m}$

archives of the National Board of Antiquities (Museovirasto).

The sites represent the successive stylistic phases and sub-phases of the Neolithic combceramic (Ka) culture, from the earliest $\mathrm{Ka} \mathrm{I}: 1$ to the latest $\mathrm{Ka}$ III:2, and the late Neolithic Kiukais $(\mathrm{Ki})$ culture. The age range of the phases is indicated in Fig. 5. No exact date is available for the end of Ka III:2. The lower limit of the finds or the cultural layer at a dwelling site of a given cultural phase can usually be taken to indicate the position of the sea level at a time point marking the end of that phase (cf. Siiriäinen 1969, pp. $59-60)$.

The altitudes of the dwelling sites from different parts of the area were not corrected for unequal land uplift, as were the altitudes of the stratigraphical sites, but the total present vertical range within the area is given in Fig. 5 for those phases represented by more than one site. However, the upper limit of each phase is set by sites at Sperrings and Finns situated between the isobases of Odilampi and Lammaslampi, and a curve drawn according to these uppermost sites should form an approximate continuation to the curve based on the stratigraphical data.

The dates given to the Stone Age cultural phases, particularly those for the younger ones, are essentially shore-line gradient dates, that is, they are derived from the gradients of the different Stone Age shore lines (Siiriäinen 1972). The basic assumption in this dating is that the land uplift has decelerated in a regular manner from the deglaciation to the present time, and thus a gradient/time curve describing the decrease with time of the shore-line gradients can be drawn with the aid of a few synchronous levels whose tilt and (radiocarbon) age can be accurately determined. The ages of all the other shore lines with known gradients can be established from this curve. Strictly speaking, the use of gradient ages for studying shore displacement involves an element of circular reasoning. In practice, however, the regular deceleration of land uplift in southern Finland seems to be well established (Donner 1970, Saarnisto 1971), and thus the accuracy of the Stone Age gradient dates depends on the uncertainties in determining the shore lines by the dwelling sites and on the reliability of the (older) levels of reference used in constructing the gradient/time curve. Siiriäinen (1972, pp. 9-10) estimated that the theoretical margins of error in his dates, due to factors of uncertainty in determining the tilt of the shore lines, vary between \pm 40 and \pm 130 years, but, as he points out, the factual uncertainties are greater when a shore line is based on a few sites only.

The youngest stratigraphical and the oldest archaeological points of reference in the present material are in good mutual agreement. They are consistent with an even, slow regression of the shore level around 6000 B.P. At this point, there is an apparent discrepancy between the present curve and the curve by Siiriäinen (1972) for the same uplift area based exclusively on archaeological evidence. In the latter, the Mesolithic Suomusjärvi (S) period, which immediately precedes the comb-ceramic period in the cultural succession, is represented by sites a couple of 
metres lower than the earliest comb-ceramic (Ka I:1) sites, suggesting transgression during the Ka I:1 phase. No such transgression could be accommodated to the present curve, because at the end of the $\mathrm{S}$ period $(\mathrm{S} / \mathrm{Ka}$ boundary) the water level cannot have been lower than the threshold of Gallträsket, which is $1-2 \mathrm{~m}$ above the nearby $\mathrm{Ka} \mathrm{I}: 1$ sites.

The curve by Siiriäinen is based on a shore-line diagram that combines the data from the whole of southern Finland along zones of approximately equal land uplift. The critical $\mathrm{S}$ sites are from Askola about 50 $\mathrm{km} \mathrm{ENE} \mathrm{of} \mathrm{Helsinki}{ }^{1}$, and the discrepancy is really between the data from these two areas. Eronen (1974, pp. 124-125) has previously discussed this discrepancy in some detail (see also Hyvärinen 1979). Besides the archaeological evidence, stratigraphical indications of relative transgressions have also been reported from Askola (Virkkala 1953, Tynni 1966). Tynni distinguished as many as three separate Litorina transgressions in this area. A further detail, already noted by Äyräpää (1929), is the exceptionally large difference in altitude between the $\mathrm{Ka} \mathrm{I}$ and $\mathrm{Ka}$ II sites at Askola. Thus, whereas Askola and Helsinki show similar values for the modern uplift and for the altitude of, for example, the Ka I:1 sites, Askola would seem to have experienced fluctuations in relative sea level not recorded at Helsinki. If real, such differences must be due to local irregularities in land uplift near Askola, a conclusion suggested by most previous authors.

No stratigraphical and radiocarbon control is available for the rest of the curve. The

1 The lowermost $\mathrm{S}$ site so far known from the immediate vicinity of Helsinki is Kilteri at $34 \mathrm{~m}$ a.s.l. (Väkeväinen 1975). Judging by its altitude, this site cannot represent the end of the S period; it must be older, as is also suggested by the radiocarbon age $7050 \pm 170$ B.P. (Hel-599) obtained from the site. The age range of the $\mathrm{S}$ culture is large, extending back to Ancylus times, and the $\mathrm{S}$ sites also show a wider vertical distribution than Neolithic sites usually do. total archaeological data from southern Finland point to an accelerated regression in shore displacement immediately after the $\mathrm{Ka}$ I:1 phase, followed by a retardation during $\mathrm{Ka}$ II and Ka III (Siiriäinen 1972). As would be expected, these trends can also be distinguished in the material from the Helsinki area, if analysed in detail, although they are not expressly shown by the present curve. It will be noticed that the detailed course of the curve would be affected by relatively small adjustments (50-100 years) in the dating of the archaeological phases.

\section{Discussion}

The main conclusions from the shore displacement curve can be summarized as follows. For a period of almost 2000 years from 8000 to 6000 yr B.P. the relative sea level at Helsinki was at first stable or slightly transgressive and then, during the latter part of the interval, subject to an even, slow regression. During much of this period land uplift was broadly compensated by eustatic sea-level rise. Stratigraphical data allow the position of the shore level to be fixed with an accuracy of about one metre. No shortterm fluctuations larger than that seem to have occurred. Hence, both the local uplift and the eustatic rise must have progressed evenly during this interval; it would be difficult to see any sea-level fluctuations exactly cancelled out by coincident irregularities in the land uplift.

At the same time as the results from Helsinki specifically show that the eustatic curves with several sharp fluctuations up to five metres in amplitude around 8000 to 6000 yr B.P. (Fairbridge 1961, Ters 1973) cannot possibly apply to the present area, they are generally consistent with the $»$ Baltic Eustatic Curve» by Eronen (1974), which shows an even rise in ocean levels before 6000 yr B.P. and a broad culmination around 
5000 yr B.P. (cf. also Köster 1961). Small fluctuations less than one metre (cf. Mörner 1969, Berglund 1971, Tooley 1974, 1978) cannot be excluded. Nonetheless, the existence of such fluctuations is very difficult to demonstrate because of the limitations of the methods available and the risk of including purely local events.

As Eronen (1974) has argued, it is probable that the multiple-transgression character of the Baltic Litorina is apparent rather than real. One and the same transgressive event will have a regionally metachronous expression as the eustatic rise catches up with the isostatic movement at different time points in zones of different uplift. The picture is further complicated by local shoredisplacement events and by spurious events based on evidence open to interpretation. A number of such cases are critically discussed by Eronen (1974, pp. 115-121). Especially in older studies in Finland, the mere presence of small percentages of halophilous diatoms has often been taken to indicate brackish conditions due to a direct Baltic connexion, and sites similar to that of Odilampi described in this paper have been interpreted in terms of transgression. The triple Litorina transgression reported by Tynni (1966) from Askola, for instance, rests partly on such evidence. On the other hand, as discussed above, local irregularities in land uplift probably also occurred in this area. Note, however, that large irregularities need not necessarily be involved; during periods of very slow or zero shore displacement, relatively small deviations from regular uplift, or even more local causes, may produce apparent transgressions in coastal basins and lagoons. In fact, such events would be expected, and therefore single stratigraphical sites with transgressive layers can be unreliable indicators of sea-level changes.

The above conclusions concern directly only the older, Atlantic part of the Litorina period, for which new stratigraphical data have been presented. On the basis of archaeological evidence, Ramsay (1926) recognized a "Second Stone Age Transgression" in Subboreal times around 4500 years B.P. Eronen (1974, pp. 115-116) reviewed the overall evidence relating to this phase and concluded that there was probably no general transgression in the Baltic uplift area at that time. Still, a case could be made for a separate phase of retarded regression, possibly with a eustatic background, following the main Atlantic event. The archaeologically established shore-level curves by Siiriäinen (1972) for Helsinki and Kristiinankaupunki are consistent with such a phase. These curves may be compared with the stratigraphically established curve by Lundqvist (1963) for an area near Hudiksvall, southern North Sweden, which shows a very similar trend. On the other hand, the curve by Glückert (1976) for SW Finland (50 m Litorina isobase) provides no evidence for such a fluctuation. The more marginal parts of the Baltic uplift area, such as Blekinge in southern Sweden (Berglund 1971), have yielded indications of relative transgressions in Subboreal as well as Atlantic times (cf. also data from southwestern Norway summarized in Hafstén 1979). The stratigraphical and radiocarbon data from Finland are still insufficient for a detailed discussion of shore-level changes during the later part of the Litorina period.

Acknowledgements - I wish to thank the participants in the Quaternary palaeontology course, Department of Geology, University of Helsinki, 1979, for their assistance in collecting the Odilampi core and in analysing the samples, Mr. R. Salomaa for help in the field work, Mr. H. Matiskainen for obtaining information on the archaeological sites, Mr. H. Jungner and his staff for the radiocarbon dating, and Prof. J. Donner, Dr. M. Eronen and Dr. A. Siiriäinen for comments and discussions. Mrs. G. Häkli has checked the English of the manuscript. 


\section{References}

Aartolahti, T. (1966) Über die Einwanderung und die Verhäufigung der Fichte in Finnland. Ann. Bot. Fennici 3, 368-379.

- (1967) Zur rationellen Tilia-Pollengrenze $\left(\mathrm{T}^{\circ}\right)$ in Finnland. Fennia 97: 1, $30 \mathrm{pp}$.

Alhonen, P. (1971) The stages of the Baltic Sea as indicated by the diatom stratigraphy. Acta Bot. Fennica 92, 1-18.

- (1972) Gallträsket: The geological development and palaeolimnology of a small polluted lake in southern Finland. Comment. Biol. 57, 34 pp.

- Eronen, M., Nunez, M., Salomaa, R. and Uusinoka, R. (1978) A contribution to Holocene shore displacement and environmental development in Vantaa, south Finland: the stratigraphy of Lake Lammaslampi. Bull. Geol. Soc. Finland 50, 69-79.

Äyräpää (Europaeus), A. (1929) Askolan Honkaniemen kivikauden asuinpaikka. Muuan poikkeus maankohoamiskäyristä. Deutsches Referat: Der steinzeitliche Wohnplatz bei Honkaniemi im Ksp. Askola. Eine Abweichung von den Landhebungsisobasen. Suomen Museo 36, $15-32$.

Berglund, B. (1964) The Post-glacial shore displacement in eastern Blekinge, southeastern Sweden. Sveriges Geol. Unders. C 590, 47 pp.

- (1971) Littorina transgressions in Blekinge, south Sweden. A preliminary survey. Geol. Fören. Förh. 93, 625-652.

Donner, J. J. (1970) Deformed Late Weichselian and Flandrian shore-lines in south-eastern Fennoscandia. Comment. Phys.-Math. 40, 191 $-198$

- (1971) Towards a stratigraphical division of the Finnish Quaternary. Comment. Phys.Math. 41, 281-305.

- (1972) Pollen frequencies in the Flandrian sediments of Lake Vakojärvi, south Finland. Comment. Biol. 53, 1-19.

- Alhonen, P., Eronen, M., Jungner, H. and Vuorela, I. (1978) Biostratigraphy and radiocarbon dating of the Holocene lake sediments of Työtjärvi and the peats in the adjoining bog Varrassuo west of Lahti in southern Finland. Ann. Bot. Fennici 15, 258280.

Eronen, M. (1974) The history of the Litorina Sea and associated Holocene events. Comment. Phys.-Math. 44, 79-195.

- (1976) A radiocarbon-dated Ancylus trans- gression site in south-eastern Finland. Boreas $5,65-76$.

Fairbridge, R. W. (1961) Eustatic changes in sea level. In Ahrens, L.C. et al. (eds): Physics and Chemistry of the Earth 4, 99-185. Pergamon Press.

Fontell, C. W. (1926) Om brak- och saltvattendiatomacéers förekomst i sött vatten i närheten av kusten. Acta Soc. Fauna Flora Fennica 55: 7, 3-21.

Florin, M.-B. (1946) Clypeusfloran i postglaciala fornsjölagerföljder i östra Mellansverige. Geol. Fören. Förh. 68, 429-457.

Glückert, G. (1976) Post-glacial shore-level displacement of the Baltic in SW Finland. Ann. Acad. Sci. Fennicae A III 118, 92 pp.

Hafstén, U. (1979) Late and post-Weichselian shore level changes in south Norway. In Oele, E., Schüttenhelm, R.T.G. and Wiggers, A.J. (eds): The Quaternary history of the North Sea, 4559. Acta Univ. Upsaliensis, Symposia Univ. Upsaliensis Annum Quingentesimum Celebrantis 2 .

Hyvärinen, H. (1979) Helsingin seudun rannansiirtyminen Litorina-aikana Sipoosta tutkitun näytesarjan valossa. (Bakunkärrsträsket: a stratigraphical site relevant to the Litorina shore displacement near Helsinki.) Terra 91, 15-20.

Hyyppä, E. (1937) Post-glacial changes of shoreline in south Finland. Bull. Comm. géol. Finlande $120,225 \mathrm{pp}$.

- (1950) Helsingfors omgivningar. Beskrivning till jordartskarta. Geologiska Forskningsanstalten, Helsingfors.

Köster, R. (1961) Junge eustatische und tektonische Vorgänge im Küstenraum der südwestlichen Ostsee. Meyniana 11, 23-81.

Lundqvist, G. (1963) Beskrivning till jordartskarta över Gävleborgs län. Sveriges Geol. Unders. Ca 42,181 pp.

Mörner, N.-A. (1969) The Late Quaternary history of the Kattegatt Sea and the Swedish west coast. Deglaciation, shoreline displacement, chronology, isostasy and eustasy. Sveriges Geol. Unders. C 640, 487 pp.

Ramsay, W. (1926) Nivåförändringar och stenåldersbosättning i det baltiska området. Fennia 47: 4, $67 \mathrm{pp}$.

Saarnisto, M. (1971) The history of Finnish lakes and Lake Ladoga. Comment. Phys.-Math 41, 371-388. 
Siiriäinen, A. (1969) Über die Chronologie der steinzeitlichen Küstenwohnplätze Finnlands im Lichte der Uferverschiebung. Suomen Museo $1969,40-73$.

- (1972) A gradient/time curve for dating Stone Age shorelines in Finland. Suomen Museo 1972, 5-18.

- (1973) Studies relating to shore displacement and Stone Age chronology in Finland. Suomen Museo 1973, 5-22.

Ters, M. (1973) Les variations du niveau marin depuis 10,000 ans, le long du littoral atlantique français. Assoc. Française pour l'Etude du Quaternaire, Suppl. au Bull. 36, 114-142.
Tooley, M. (1974) Sea-level changes during the last 9000 years in north-west England. Geogr. J. $140,18-42$.

- (1978) Interpretations of Holocene sea-level changes. Geol. Fören. Förh. 100, 203-212.

Tynni, R. (1966) Über spät- und postglaziale Uferverschiebung in der Gegend von Askola, Südfinnland. Bull. Comm. géol. Finlande 223, 97 pp.

Virkkala, K. (1953) Altitude of the Littorina limit in Askola, southern Finland. Bull. Comm. géol. Finlande 159, 59-72.

Väkeväinen, L. (1975) Vantaan Kilterin hautalöydöt. Referat: Die Grabfunde in Kilteri, Vantaa. Suomen Museo 1975, 5-16.

Manuscript received, April 23, 1980 